\title{
観測データによる大阪湾における 高潮と高波の同時生起特性 CHARACTERISTICS OF THE SIMULTANIOUS OCCURENCE OF MAXIMUM STORM SURGE AND WAVE BY USING THE FIELD DATA IN OSAKA BAY
}

\author{
國富 將嗣 1 高山 知司 2 間瀬 肇 3 -吉岡 洋 4 \\ Shoji KUNITOMI, Tomotsuka TAKAYAMA, Hajime MASE and Hiroshi YOSHIOKA \\ 1 学生員 工修 京都大学大学院 工学研究科 （T611-0011 宇治市五ヶ庄） \\ 2 万吅- 工博 京都大学防災研究所教授 （厂611-0011 宇治市五ヶ庄） \\ 3 正会員 工博 京都大学防災研究所助教授 （T611-0011 宇治市五ヶ生） \\ 4 正会員 理博 京都大学防災研究所助手 （T611-0011 宇治市五ヶ庄）
}

\begin{abstract}
At present, waves and storm surges are predicted by the numerical simulation to determine the design wave and water level for designs of storm surge barriers. In the designs, maximum extreme wave and highest storm surge are employed as the design wave and water level without consideration of the possibility of their simultaneous occurrence. Possibility of the simultaneous occurrence is of great importance to check the effectiveness of the present storm barriers on the protection of storm surges.

In the present paper, the characteristics of the simultaneous occurrence of maximum storm surges and waves have been investigated by analyzing the field data in Osaka bay. The results of the investigation conclude that the simultaneous occurrence of maximum storm surges and waves depend mainly on the course and speed of typhoons.
\end{abstract}

Key Words : Simultaneous occurrence of storm surge and wave typhoon course, typhoon speed, storm surge, extreme wave

\section{1. 研究目的}

防潮堤の設計に必要な設計波や設計水位の設定に おいて波浪推算や高潮推算が用いられている。これ らの推算は，設計地点に最も大きな高潮が生起した 台風経路に既往最大規模の台風（伊勢湾台風など） が進行するとして，計算される，高潮と高波は別々 に計算され，それぞれの最大值が設計に用いられる. このことは, 高潮と高波の最大値が同時に生起する ことを想定していることになる. しかしながら，高 潮と高波が同時に生起する可能性（同時生起特性） については，その実態が十分に把握されているとは 言えない．高潮位と高波高の発生時刻がずれること も考えられる.

また，既存の防潮堤の中には，築後20，30年程度 が経過したものもあり，これらにおいては，老朽化 や自然外力の変化などを考慮して, 嵩上げなどの改 築・補強工事が行われている. 既存防潮堤の適切な 安全度を評価するためには, 高潮と高波の生起特性 を十分に把握することが重要である.

高潮と波浪の最大值が発生する時刻に着目した研
究は少ないが，土屋ら"1) は，高潮と高波の生起時間 に差があることによって被害が軽減されていると述 ベている.

そこで本研究では，大阪湾を対象とし，実測デー 夕を用いて高潮と高波の同時生起特性についてその 実態を把握するものである.

\section{2. 観測資料}

\section{（1）海象・気象資料と観測期間}

調查対象海域は大阪湾とした。大阪湾沿岸で潮位 および波浪といった海象データが長期にわたり観測 されている地点は, 関西国際空港（以後関空と略 称）, 神戸港, 大阪港, 洲本, 淡輪の5地点である. これらの各地点から潮位（全地点）, 波浪（関空, 神戸，大阪）デー夕を収集した。 また，気象デー夕 （風データ）も求めたが, 関空を除く各地では, 1991年以降のデータしか入手できなかった. なお観 測地点の詳細位置を図-1に示す。

海象データは, 財団法人日本海洋データーセン 
ター, 関西国際空港株式会社, 運輸省, 大阪市の各 機関が観測しているものを使用した。風データは, 気象業務支援センター発売のものを使用した. なお, データの観測時間間隔は, 2時間であった.

解析の対象とする観測期間は, 大阪湾に顕著な高 潮・高波を引き起こさせたと考えられる台風を選定 して決定した. 台風を選定した期間は, 得られた観 測データの有無を考慮して，1978年から1994年まで とした．参考に用いた資料としては，高波の発生時 期と気象要因を調べるために，運輸省港湾技術研究 所発行の「港湾技研資料，波浪に関する拠点観測年 報（毎年）」を，高潮は気象庁発行の潮汐観測（昭 和 63 年から平成 5 年) を用いた。 また, 台風経路の チェックを行うため，（財）日本気象協会発行の 「気象要覧」（1978年から1994年の該当月）と, 月 刊誌「気象」（1980年から1994年）掲載の天気図を 参考に用いた．これらの資料を基にして11個の台風 を選定し，考察対象の観測期間を設定した.

なお，潮位に関しては，黒潮の影響2)を考慮せず， 高潮偏差を求めている.

\section{（2）台風資料}

同時生起特性の傾向をより簡単に評価するために, 台風経路を数種の型式に分類して検討を行った. こ こでは, 気象庁で採用している台風経路3)による分 類法を適用した. 結果的には, II 型からVII 型の6種 類に分類できた. 以下に経路ごとの特徵を簡単に述 ベる.

a）台風経路 II 型（九州の西方海上から北東へ進む 場合）北緯 30 度を越えるときに東経が 130 度以西で, 九州に上陸せず，九州西海上から朝鮮海峡を通る台 風で, 日本海側に上陸する場合もありえる.

b) 台風経路III 型（九州を北上する場合）北緯 30 度 を越えるときに東経が130 133度で, 九州へ上陸し, 九州を南から北へ進む台風である.

c）台風経路IV型（九州を北東へ進む場合）北緯 30 度を越えるときに東経が 130 度以西で, 九州へ上陸 し, 九州西岸から東岸へ横断する台風である.

d）台風経路 $\vee$ 型（四国を北上する場合）北緯 30 度 を越えるときに東経が132〜135度の範囲で, 四国に 上陸し，四国を南から北へ縦断する台風である.

e）台風経路VI型（四国を北東進する場合）北緯 30 度を越えるときに東経が133度以西で，四国に上陸 し，四国を北東に横切る台風である. ただし，九州 には上陸しない。

f）台風経路VII型（紀伊半島を北上する場合）北緯 30 度を越えるときに東経が137度以西で, 紀伊半島 に上陸し, 半島を北進, または北東進する台風であ る.

最終的に選定した台風の経路形式と，デー夕を抽 出した観測期間を, 表-1にまとめる. また，これら の経路形式を図-2, 各台風の経路を図-3に示す.

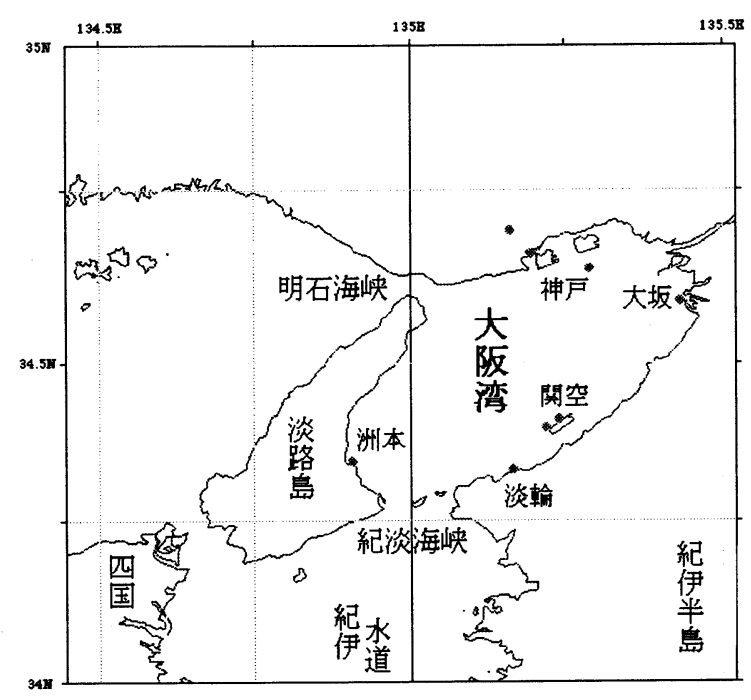

図-1大阪湾における観測地点

表-1 台風の経路型式と解析対象期間

\begin{tabular}{|c|c|c|c|}
\hline \multirow{3}{*}{$\begin{array}{l}\text { 解析 } \\
\text { 対象 } \\
\text { 台風 }\end{array}$} & \multirow{3}{*}{$\begin{array}{l}\text { 台風 } \\
\text { 経路 } \\
\text { 型式 }\end{array}$} & \multirow{2}{*}{\multicolumn{2}{|c|}{$\begin{array}{l}\text { 解析対象 } \\
\text { 観測期間 } \\
\end{array}$}} \\
\hline & & & \\
\hline & & 開始 & 終了 \\
\hline T7916 & $\mathrm{VI}$ & $09 / 30$ & $10 / 01$ \\
\hline T8013 & III & $09 / 11$ & $09 / 12$ \\
\hline T8213 & III & $08 / 27$ & $08 / 28$ \\
\hline T8219 & $\mathrm{V}$ & $09 / 24$ & $09 / 26$ \\
\hline T8410 & II & $08 / 21$ & $08 / 22$ \\
\hline T8712 & II & $08 / 30$ & $08 / 31$ \\
\hline T8917 & $\mathrm{VI}$ & $08 / 26$ & $08 / 28$ \\
\hline T9019 & VII & $09 / 19$ & $09 / 20$ \\
\hline T9119 & IV & $09 / 27$ & $09 / 28$ \\
\hline T9313 & $\mathrm{IV}$ & $09 / 03$ & $09 / 04$ \\
\hline T9426 & VII & $09 / 29$ & $09 / 30$ \\
\hline
\end{tabular}

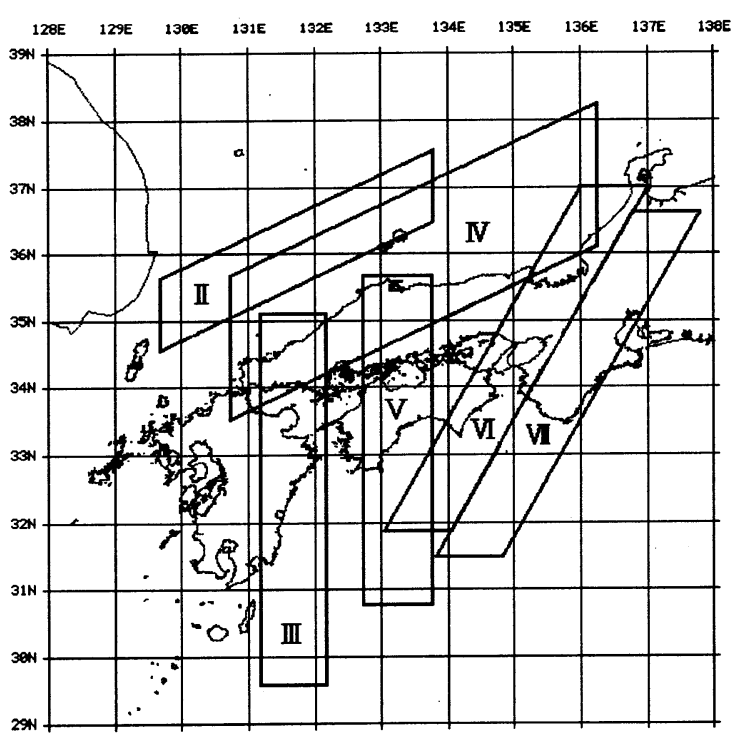

図-2 台風経路形式 


\section{3. 高潮と高波の同時生起特特性}

前述の資料を用いて, 各台風経路ごとに高潮と高 波の同時生起特性について調べた. 各台風における, 高潮と高波の最大値の生起時間差についてまとめた 結果を表-2に示す. 表中, 正の時間差は高潮よりも 高波が遅く, 負は早く生起したことを示す. 各経路 における同時生起特性は, 以下の通りである.

\section{（1）台風経路第 II 型（T8410号，T8712号）}

T8410もT8712も九州に上陸せず，対馬を経て日本 海を北東進している. T8410は中心気圧 $970 \mathrm{hPa}$, 進 行速度 $35 \mathrm{~km} / \mathrm{h}$ で対馬近海を通過したのに対し， T8712は, $945 \mathrm{hPa}, 55 \mathrm{~km} / \mathrm{h}$ という比較的強い勢力, 早い速度で通過しているのが特徵的である.

両台風とも大阪湾からはかなり遠方を通過したが, 大阪湾各地で最大風速 $10 \mathrm{~m} / \mathrm{s}$ 以上の強い風が観測さ れた. 大阪湾は, 南西から北東にのびる楕円形をし ているため, 台風が山陰沖を北東進するときに南西 風が吹き，波が大きくなると考えられる．T8410と T8712の高潮と高波の時系列変化をそれぞれ図-4 (a)， (b)に示す.

図から，高潮はそれほど大きくはないが，高波高 が出現していることがわかる. 高波高が出現したの は, 長いフェッチとなる大阪湾の長軸方向（南西か ら北東方向）に沿った南西風によるものと考えられ る. 従って, 関空よりも北に位置する神戸ではより 大きな波高が出現している. また, 台風が山陰沖を 北東進する時間は，比較的長く，これによって長時 間にわたる南西風が大阪湾に吹き，波高が次第に大 きくなったものと考えられる.

高潮と高波の最大値の生起時間差は, 各地で $2 \sim 5$ 時間程度であった. 高潮は, 南西風が弱まり始めた 時間に最大値を迎えている. 一方，高波については， 湾内で風速が分布しており, 湾口から湾央にかけて 風速が速く，その結果，湾央で大きくなった波が高 潮に遅れて到達っしたものと考えられる．神戸にお ける2時間程度の時間差は, 湾央にあった大きな波 が神戸沿岸に到達するに要する時間である.このよ うに, 高波の最大值は, 高潮の最大値の生起時間よ りも遅く生起したと考えられる. なお, 台風が九州 西方海上を北上するため, 長周期的な湾外来襲波は 見られなかった.

\section{（2）台風経路第III型（T8013号，T8213号）}

この形式の台風は, 九州南部から上陸後, 中国地 方へ北上し日本海へ抜ける進路をとる. 大阪湾は台 風の東方に位置するため, 台風西部の南風に大きく 影響される. 該当の何れの台風も中国地方北部を北 進したため, 大阪湾からは比較的遠方を進行してい た. しかし, 大阪湾各地では $10 \mathrm{~m} / \mathrm{s}$ 以上の強い風が 観測されていた. 上陸時の台風諸元は, 中心気圧は 960 970hPaでほぼ同程度であったが, 台風の進行 速度は, T8013が比較的早かった. T8013 とT8213の

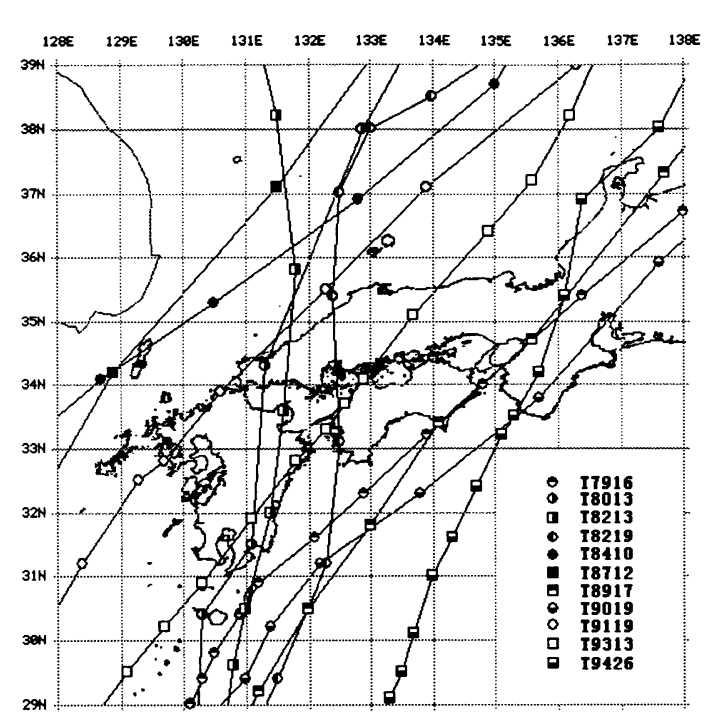

図-3＼cjkstart選定した台風の経路

表-2 高潮と高波の最大值生起時間差 (時間)

\begin{tabular}{|c||c|c|c|}
\hline 台風 & 関空 & 神戸 & 大阪 \\
\hline \hline $\mathrm{T} 7916$ & 2 & 3.5 & \\
\hline $\mathrm{T} 8013$ & 2 & 4 & \\
\hline $\mathrm{T} 8213$ & 3 & & 6 \\
\hline $\mathrm{T} 8219$ & -12 & & 1 \\
\hline $\mathrm{T} 8410$ & 2 & 2 & 5 \\
\hline $\mathrm{T} 8712$ & 0.5 & 2 & 2 \\
\hline $\mathrm{T} 8917$ & 2 & 4.5 & \\
\hline $\mathrm{T} 9019$ & 0 & 0 & \\
\hline $\mathrm{T} 9119$ & 0 & & \\
\hline $\mathrm{T} 9313$ & 0 & 1 & 0 \\
\hline $\mathrm{T} 9426$ & & 3 & 2 \\
\hline
\end{tabular}

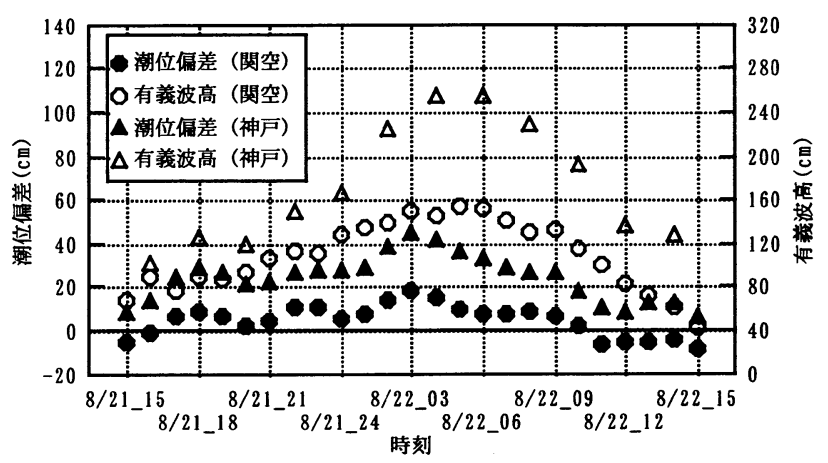

図-4（a）台風経路 II 型（T8410）高潮と高波

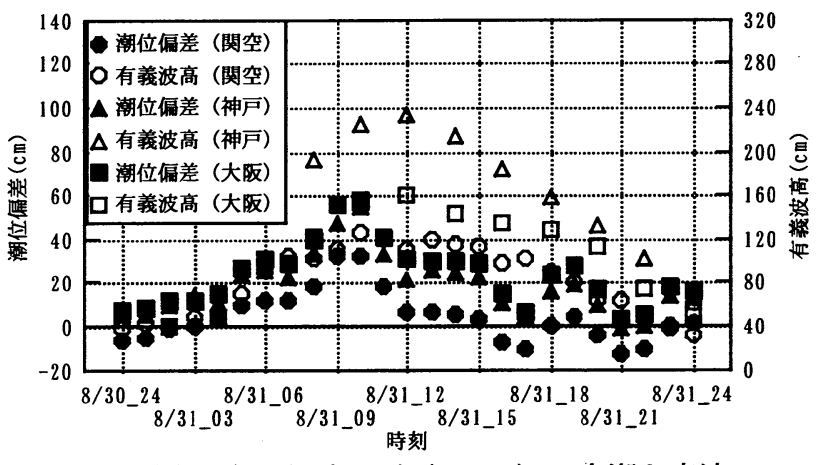

図-4（b）台風経路 II 型（T8712）高潮と高波 
高潮と波浪の時系列変化を図-5 (a)，（b)に示す.

図によると, 先の II 型と同様, 大きな波高が出現 している. この理由としては, 台風と大阪湾の位置 関係が II 型とほぼ同様であることから, 台風の南西 風の影響であると思われる.

台風の進行速度が比較的速かったT8013では, $\mathrm{T} 8213$ と比較して高潮と高波の最大值の時間差が短 い. また，高波の大きさもT8013の方が大きい。こ れは, T8013の方が大阪湾に吹く南西風が強く, 波 高が大きくなり, 高波が早く沿岸に到達したためと 考えられる. この原因としては, 台風の進行速度が 速いと, 台風南東部の南西風が強くなることにある と思われる. しかし, 進行速度が速い場合であって も, 他の台風経路よりも大阪湾における南風の持続 時間が長かった.

高潮と高波の生起時間差は, T8013の関空で+2時 間, 神戸で+4時間, T8213の関空で+3時間, 大阪で +6時間であった.このことから, 湾奥（大阪, 神 戸) の方が湾中央（関空）よりも高波の生起が遅い ことがわかる. この傾向は, II 型の台風と同様であ る. III型では, 大阪湾上を南風が長い時間吹くので より顕著に現れている.また, T8013の関空におけ る生起時間差はT8213より1時間早い。これは前述の ように, 台風の進行速度に関係し, 速ければ時間差 が短くなり, 遅ければ長くなる傾向を示す.

\section{（3）台風経路第IV型（T9119号，T9313号）}

本型式の台風は, 九州を南西から北東に横切り, 本州付近を南西から北東進する傾向が強く, 日本に 来襲する台風のうち数が最も多いものである. 昭和 20 年の枕崎台風や昭和 29 年の洞爺丸台風, 近年では 台風9119号など, 我が国に甚大な被害を与えた台風 が，この経路に該当する. 特徵的な事項としては, 台風が山陰沖から日本海を北東に進む時に大阪湾に 最接近し, かつ強い南西風をもたらすことが挙げら れる. 特に台風の進行速度が速い場合, 台風南東部 の南西風が強くなるため, 湾北東部での高潮, 高波 被害などが懸念されるものである.

該当の台風はT9119 と T9313である. 何れの台風も 非常に強い勢力を持って九州に上陸, 北東進した. $\mathrm{T} 9119$ は佐世保上陸時の中心示度が $940 \mathrm{hPa}$, 最大風 速 $50 \mathrm{~m} / \mathrm{s}$, 北東に $50 \mathrm{~km}$ で進行した. 近年では稀な激 しい風を伴った台風であったため気象学的な研究も 多い（例えば藤井 ${ }^{4 ）} 1992 ）$. 強風半径は600kmで あったため, 大阪湾をも勢力下にしていた．T9313 は, 中心気圧は中国地方上陸時で $975 \mathrm{hPa}$, 進行速度 は40km程度であった. またT9119に比して東寄りの 進路をとったため, 大阪湾への影響も大きかったと 考えられる. 何れの台風も他型式の台風に比して大 きな勢力, 強い風を持つのが特徵的である. なお, T9119では関空以外の地点で波浪データが得られて いなかった.

両台風の高潮と高波の時系列変化を図-6 (a), (b) に示す.この図からわかるように, 高潮, 高波とも

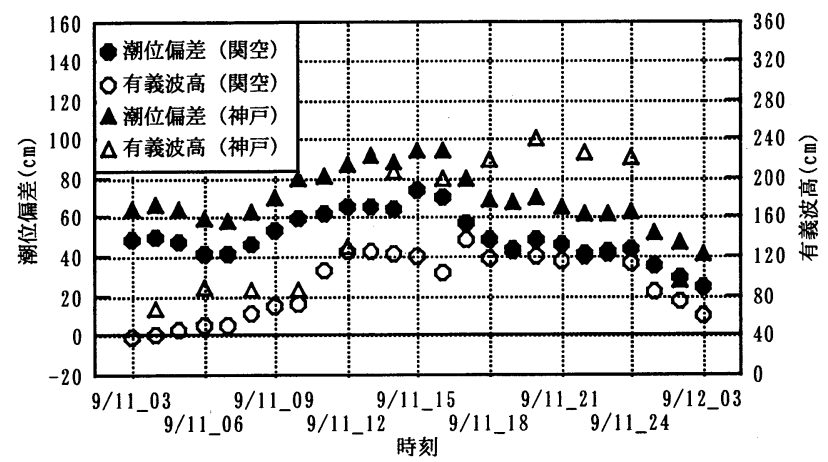

図-5（a） 台風経路而型（T8013） 高潮と高波

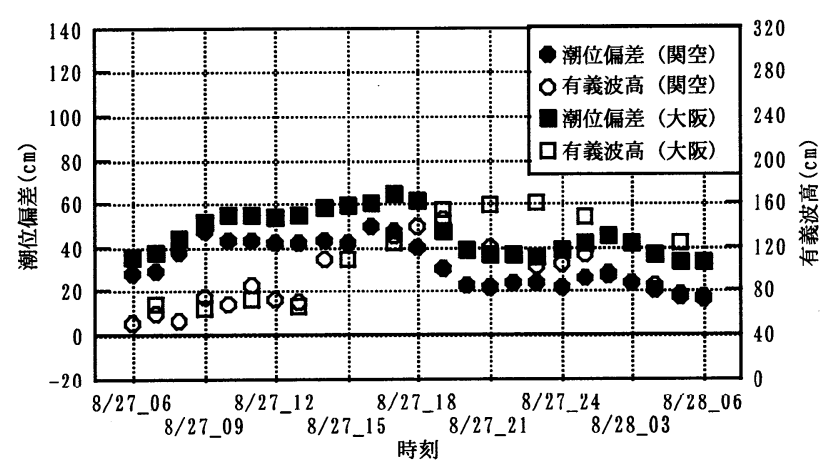

図-5（b）台風経路而型（T8213） 高潮と高波

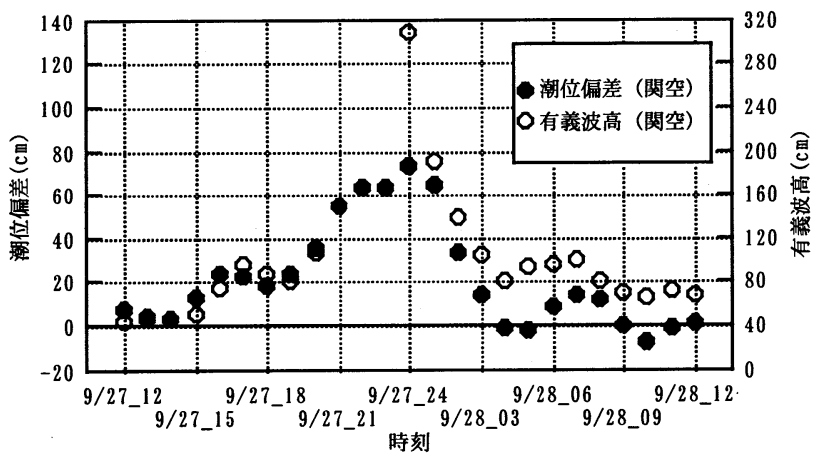

図-6（a）台風経路IV型（T9119）高潮と高波

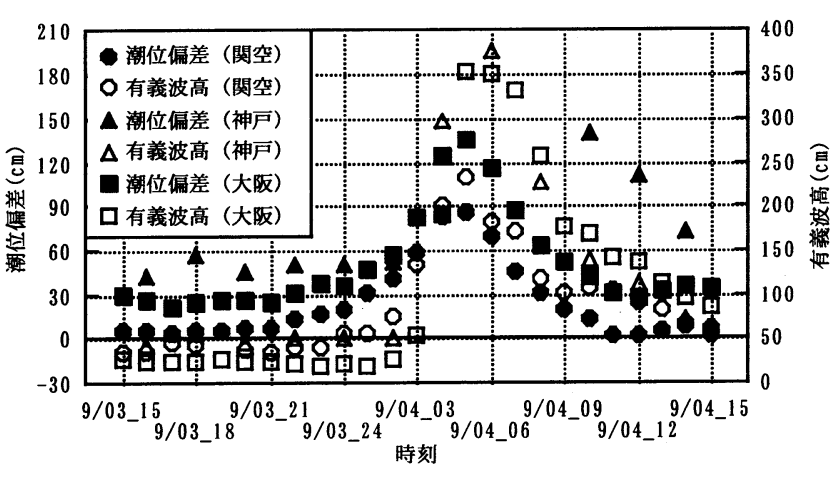

図-6（b）台風経路IV型（T9313） 高潮と高波

急激な成長を遂げ，短時間で最大值が出現している のが特徵的である.これは, 台風の強い勢力域の外 縁（台風南東部）が大阪湾をかすめるような形で通 過するため, 短期間に強風が出現することによるも のと考えられる. また, 台風の進行方向に対して右 側の領域で風速が強くなるという気象傾向にも影響 され, 南西風がより強く影響しているものと考えら 
れる。

同時生起の傾向としては，図からもわかるように 高潮，高波ともほぼ同時刻で最大値が生起している。 特に，湾北部での有義波高と潮位偏差は，選定した 台風の内, 最も高い值を観測していた。台風の進行 速度および台風の規模が異なる場合，大阪湾上を吹 く南西風の出現時間に差違が生じ，高潮・高波の生 起時間に影響を及ぼすもりと考えられる.

この台風経路の場合, 高潮最大值が生起する時の 台風の位置が大阪湾北西であるため, 大阪湾は常に, 南西風をもたらす台風南東部に相当することになる. 従って，大阪湾と台風の相対的な位置関係が変わら ない限り, 高潮と高波の生起時間に差が生じないも のと考えられる.

\section{（4）台風経路第 V 型（T8219号）}

この台風は, 四国南海上から北上し, 四国, 中国 を縦断する台風である. 昭和 18 年7月の 12 号台風や 昭和25年のジェーン台風が主な例である．その経路 からわかるように, 大阪湾は台風東部にあたり, 特 に湾北部での高潮が生起しやすい。選定した台風の 内，本経路に該当したのはT8219のみであった.

台風は大阪湾の西方を北上するため, 大阪湾では 台風西部の影響を受け，南風が支配的となる．また， 台風が四国南海上から北進するため, 外洋で発達し た波浪のうねり成分が大阪湾に影響を及ぼす可能性 もある.

図-7に示すように，関空での高潮と高波の生起時 間差は-12時間であった. 南風による最大值のみに 着目すればほぼ同時に生起しているが，北東風によ る波浪の最大值が出現していることは特筆すべき現 象である．これは，台風が四国南方にあるときに大 阪湾で東〜北東の風が吹くことによるものと考えら れる。一方，大阪では南風のみの影響を受けて波浪 が発達するため, 高潮の最大值とほぼ同時に有義波 高の最大值を観測している.この南風による生起時 間差は, 他の型式の台風とほぼ同様な傾向を示して おり, 台風進行速度に伴う風の場の相違によって差 が生じるものと考えられる.

\section{（5）台風経路第VI型（T7916号，T8917号）}

この経路は, 昭和 9 年 9 月 21 日の室戸台風, 昭和 36 年9月の第 2 室戸台風が例として挙げられ，大阪湾 における最も危険な経路として知られる．台風の特 徵としては, 上陸直前に急激な発達を遂げることや, 必ず瀬戸内沿岸に異常な高潮を発生させることにあ る. また，この経路は，大阪湾における防潮堤の設 計波と設計潮位を選定するときに想定している台風 経路が含まれる。この型式に該当した台風は, T7916 とT8917であった. 何れの台風も四国東部を北 東に通過した後, 紀伊水道北部から大阪湾に侵入し, 大阪湾東岸を北東進している。T7916の中心示度は 大阪湾通過時で約 $960 \mathrm{hPa}$, T8917は975hPaであった. また，大阪湾上空を通過するときの進行速度は，両

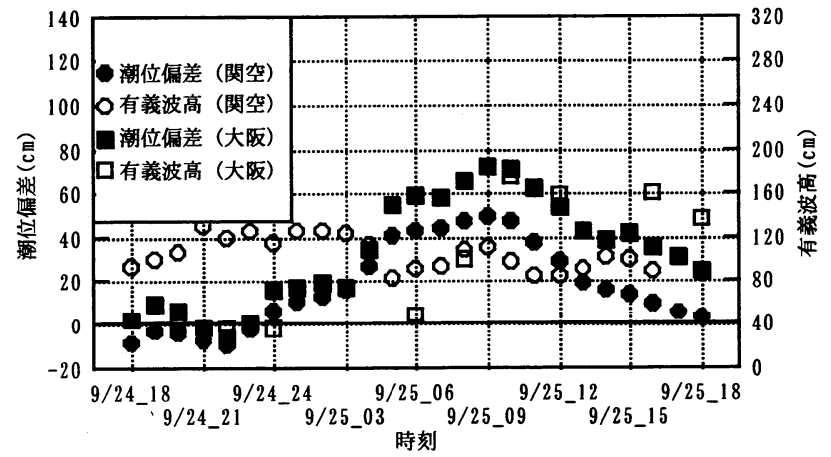

図-7 台風経路 V 型（T8219）高潮と高波

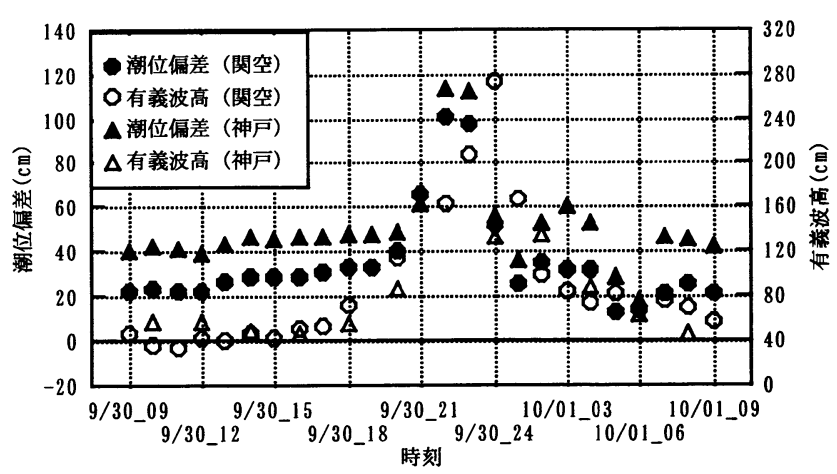

図-8（a） 台風経路VI型（T7916） 高潮と高波

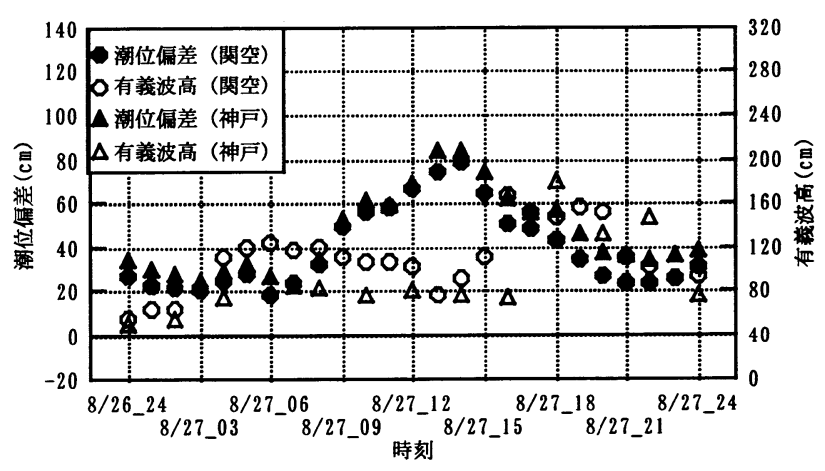

図-8（b）台風経路VI型（T8917）高潮と高波

者とも $60 \mathrm{~km} / \mathrm{h}$ 前後の比較的速い速度を持っていたこ とが特徵的である.この時の高潮と高波の時系列変 化を図-8(a)，（b)に示す.

図から，各地点とも高波が高潮よりも2〜4時間程 度遅れて生起していることがわかる. 関空と神戸港 における高潮と高波の生起時間差を比較すると, 両 台風とも関空の方が 2 時間，神戸が 4 時間と神戸の方 が遅い。これは高波浪の出現が, 主に台風が通過し た後に生じる西から南よりの風によって発達するた めと考えられる. 従って, 大阪湾上陸後の進行速度 が, T7916，T8917共に60～70km/h とほぼ同程度で あったことで, 同じ生起時間差を持ったものと思わ れる.

T7916とT8917は，共に大阪湾東岸を准んだため， 大阪湾に吹く南西風は, 台風が大阪湾を通過した後 に生起していた。しかし，同型の経路でも台風が大 阪湾西岸を北東進した場合，大阪湾に南西風が吹く のは, 台風が大阪湾の北西に位置したときである. 
従って, 大阪湾ではより強い南西風が吹く可能性が あり, 台風進路の微妙な相違についてより詳細な検 討を要するものと考えられる.

\section{（6）台風経路第VII型（T9019号，T9426号）}

昭和 36 年9月 26 日の伊勢湾台風がこの経路である. この台風は, 伊勢湾沿岸で未曾有の高潮災害となっ たが, 大阪湾では大きな被害はなかった．この経路 の台風は, 太平洋上から次第に四国の南海上を経て 紀伊半島に上陸, その後北進または北東進する.こ れに伴って, 大阪湾では北東の風が吹くために, 神 戸や大阪では大きな波高は発生しないと考えられる.

T9019 とT9426がこれに該当する台風である.

T9019 とT9426号は, 共に大型で強い勢力（中心示度 は共に約 $950 \mathrm{hPa}$ ）で上陸し， $30 \sim 40 \mathrm{~km} / \mathrm{h}$ で北東進し た. 両者の相違は, 勢力や最大風速ではあまり見ら れなが, 上陸前後の進路がT9019はほぼ北東進, T9426が北北東進であり, 大阪湾との相対的な距離 が異なる．大阪湾は，これらの台風に対して西側に 位置し，北風または北東風の影響を受けるものと考 えられる。

図-9 (a)，（b)にT9019 とT9426の大阪湾における高 潮と高波の時系列変化を示す. 関空で大きな波高が 出現しているのが特徵的である. T9019では関空, 神戸とも同時, T9426では神戸で+3時間，大阪で+2 時間の生起時間差であった. 欠測が多く, より詳細 な判断はできないが, 関空での高波の生起時間は北 東風に影響されるため高潮最大値の生起時間よりも 前となる可能性がある．神戸，大阪での生起時間差 は，これまで他型式の台風でも述べたように，高潮 の最大值が生起する前後の台風の進行速度に依存し ていると考えられる. ただ，T9019の神戸での生起 時間差は, 多くても1時間程度であったと考えられ る.これは, 台風の進路が紀伊半島南東部を通過し て伊勢湾に抜けて北東進しているため, 台風と神戸 との相対距離が遠く, 西よりの風の影響が比較的小 さかったことが原因と考えられる.

\section{4. 結論}

以上のことから高潮と高波の同時生起特性は，経 路と台風の進行速度に大きく依存していることがわ かった.

大阪湾は, 南西から北東に伸びる楕円形をした地 形をしているこしから, 湾北東部では南西風によっ て高潮と高波が出現する. その最大值の出現時間は, 大阪湾上を吹く南西風の強さと継続時間に依存して いることがわかった. 従って, 台風と大阪湾の相対 的な位置関係と, 台風の進行速度によって高潮と高

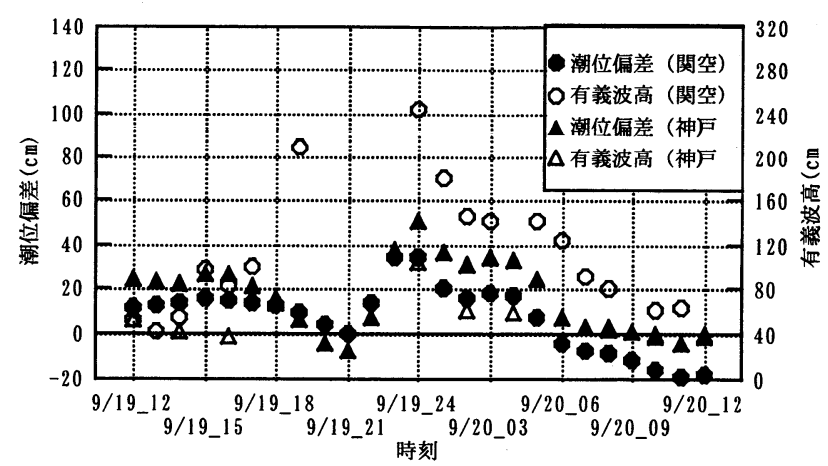

図-9（a）台風経路VII型（T9019）高潮と高波

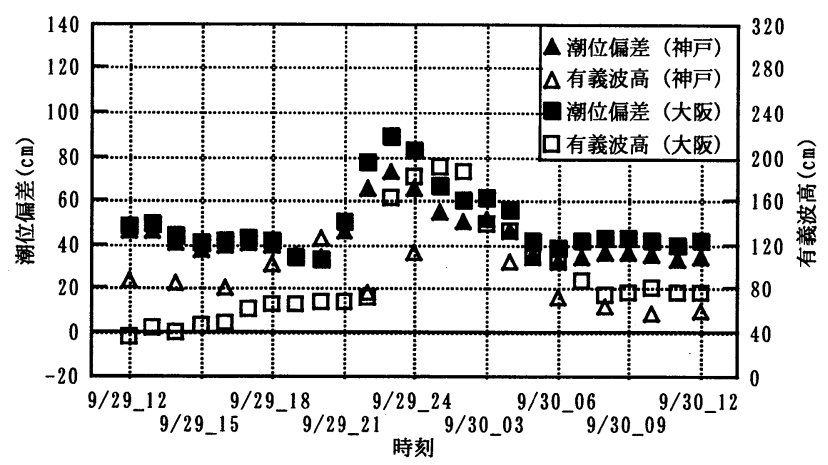

図-9（b）台風経路VII型（T9426）高潮と高波

波の最大值が同時に生起するかどうかがある程度決 まってくることがわかった. また, 本研究で取り上 げた台風のうち, IV型の経路を経る台風において, 高潮位, 高波高が同時に生起することがわかった.

大阪湾における防潮堤の設計波は, 本研究におけ るVI型の台風経路を想定して選定されているが，設 計において想定されている高潮と高波の同時生起と いう現象は, 必ずしも実際の現象として生起してい なかった：しかしながら，T7916の経路は大阪湾東 岸を北東進しており, 大阪湾上の微妙な経路の相違 が高潮と高波の同時生起性に影響を及ぼす可能性が あり, より詳細な調査が必要であると思われる.

\section{参考文献}

1）土屋義人, 中村重久, 山下隆男, 岡 扶城 : 台風7916 号による大阪湾 - 紀伊半島の高潮, 京都大学防災研究所 年報，第24号 B-2，1981.

2）山下隆男, 山本圭介, 土屋義人: 伊勢湾, 大阪湾・紀 伊水道, 土佐湾における異常潮位, 高潮に及ぼす黒潮の 影響, 京都大学防災研究所年報, 第31号 B-2, 1988 3）財団法人 日本気象協会編：続 台風災害を防ごう一 昭和 38 年 42 年, 財団法人 日本気像協会, 昭和 43 年 4）藤井 健：台風9119号による強風の気象学的特性につ いて, 日本風工学学会誌 第53号 P. 27-P. 35, 1992

（1999.4.19受付） 